\title{
搭乗者の体の傾きで走行方向を制御する電動車椅子の開発
}

\author{
遠藤敏夫 ${ }^{* 1}$, 飯田 陽 ${ }^{* 2}$, 田中慎一 ${ }^{* 2}$, 國立 勉 $^{* 1}$
}

\section{Development of an Electric Powered Wheelchair in which the Angle of Recline of the User's Body Controls the Direction}

\author{
Toshio Endo, Akira Iida, Shinichi Tanaka, and Tutomu Kunitachi
}

\section{Synopsis}

Japan is experiencing a situation where its population demographic is aging more rapidly than any other country in the world. It is estimated that in 15 years a quarter of the total population will be 65 years old or above. With the advent of this aging society, it is important that senior citizens can have a self-sustainable life-style.

In an attempt to assist senior citizens to experience self-reliance, the authors have studied the development of an electric-powered wheelchair in which the user can control the direction of travel by changing the angle of their body. The wheelchair is made full use of the latest sensing and information technologies. We have completed a prototype electric wheelchair that can detect the tilt angle of the user's body by incorporating an acceleration sensor and which controls the directions of travel by employing a personal computer.

Furthermore, after successful trials that have been carried out by senior citizens, we would like to expand our work to practical applications.

\section{1 .はじめに}

我が国は，世界てかってない速度で老齡者人口の割合か増 加している.Fig.1 は総務省統計局統計センタからインター ネットで公開されている「人口の推移と将来人口」の資料を もとにした , 老齡人口構成の予測グラフである ${ }^{1), 2}$. 1995 年 で老齡人口 (65 歳以上) の割合は, 全人口の $14.6 \%$ であった ものが, 2015 年には $25 \%$ ，すなわち，全人口の $1 / 4$ が老 齢人口という構成になる.さらに, 2025 年には $27.4 \%$ と $1 / 3$ に近くまで上昇する予測がなされている。一方で, 出 生率の低下とともに，14 歳以下の年少人口は減少の一途 である.生産年齢人口の減少と老齡人口の急激な増加 ,さ らには医療の進歩による長寿化は, 経済面をはじめとして 社会に大きな影響を及ぼすことは避けられない，老齢者介 護の面でも，生産年齢人口が減少すれば介護する側の人口 が減少するため, 介護される側もできる限り自立する必要 がある .

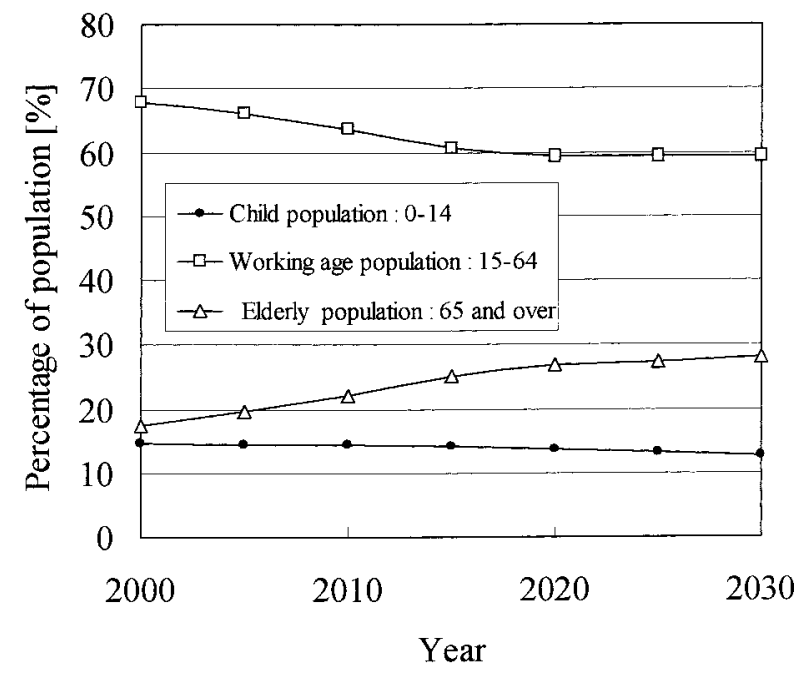

Fig.1. Japanese demographic shifts.

このような背景から，筆者らは老齢者自立の一助となる 電動車椅子の研究を進めてきた. 研究の基本的な考え方は 
「個人差に応じた自立支援機能の追加」にある . " 個人差 に応じた"の実現には「一品製作」という，コスト面の課 題を抱える.筆者らは，この課題を解決するため，市販の 電動車椅子にノートパソコンなどのモバイルコンピュー タと光の周辺機器を搭載することによって,ソフトウェア 調整のみで個別対応が可能なシステムの開発を試みてき た .すでに，市販の音声認識ソフトをノートパソコンに搭 載し,音声によって走行を制御する電動車椅子を開発して きたが, 弚れに加えて，安価な加速度センサを利用した 「搭乗者の体が傾いた方向に走行する」電動車椅子の開発 を行ったので, ここに紹介する．

\section{2 . 装置の全体構成}

この章では，「走行方向制御」部分を除く，装置の構成 について述べる.走行方向制御については次章て詳しく述 べる .

(1) 車椅子本体とモータ

車椅子本体とモータ部分は, (㛦)フブコ製の電動アシスト 車椅子を流用した .この流用したアシスト電動車椅子は初 期のモデルで, ホイールとモータがー体化されている モ一タには大同特殊鋼(㛦)か開発した Nd-Fe-B 磁石が使われ ている.また，モ一タ自体も大同特殊鋼唪で開発されたも ので, 軽量, かつ，低速高トルクという特徵を備えている． 電動アシスト車椅子は，坂道における介護者の負担を軽減 することを狙いに開発されたもので, 自走を目的としてい ないが, 平坦地では体重が $50 \mathrm{~kg}$ の搭乗者でも十分走行で
きることが確認されているので, 今回の試作に使用した . (2) 制御装置

今回試作したのは, 制御回路およびパソコン・ソフトの 部分である.制御は基本的に，パソコンで行っている. Fig.2 は制御回路の概略ブロック図で, 1 チップマイコン を用いることによって簡素な回路としている パソコンと モ一タ駆動回路との信号伝送には,マイクロチップテクノ ロジ社の1 チップマイコンである PIC16F877 ならびに Ethernet コントローラ IC(RTL8019AS) を搭載した Network Interface Card を通して行っている.制御データの通信に Ethernet を用いたのは, 今後，電動車椅子とネットワーク カメラを組み合わせ ,インターネットを介して遠隔地より 介護が可能なシステムを構筑するためである このような 介護システムは，これから更なる発展が予測されるネット ワーク社会において利用される在宅介護システムとして 実用化されるものと考える . Network Interface Card とパソ コン間の通信は無線 LANを用いた .

(3) 衝突防止装置

ここでは,超音波送信素子から発せられる周波数 $40 \mathrm{kHz}$ の超音波が,障害物で反射されて受信素子に戻る迄の時間 から, 電動車椅子と障害物との距離を測定する,簡単な原 理の超音波距離計を ADC 内蔵の1チップマイコンを中心 とする回路で実現し，電動車椅子に取り付け，これを衝突 防止装置とした . 超音波距離計については，ごく一般的な 構造であるため, 詳細は省く .

障害物検出テストの結果, 超音波の反射を利用した衝突

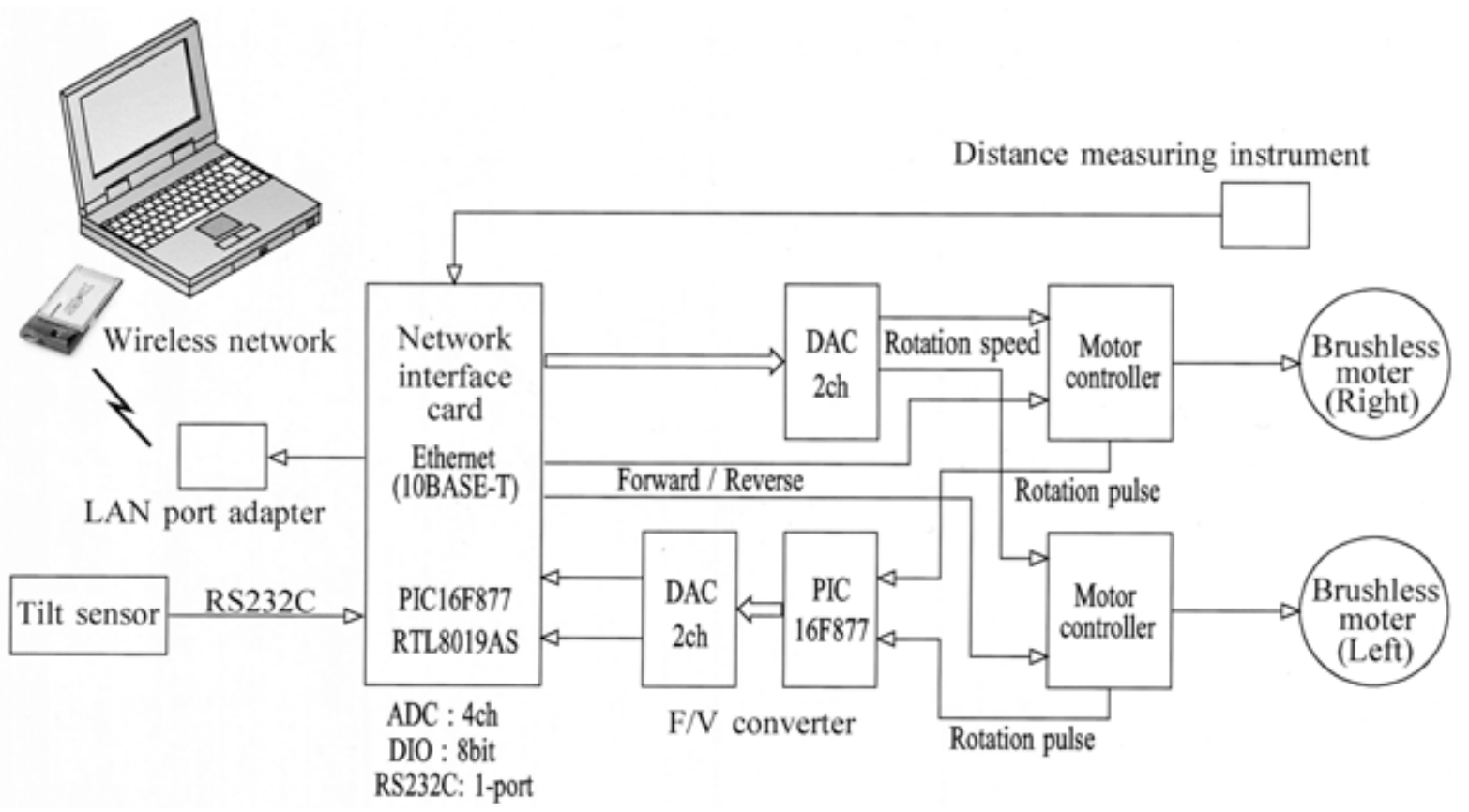

Fig.2. Block diagram for the control system. 
防止装置は，壁のような固体の障害物が対象であれば安全 装置として用いることが可能であることを確認した .しか し,障害物が"人 "の場合には検出動作が不安定で，人が 立っている位置によって反射波が検出できないことが確 認された . Fig.3 は，㚇のことを説明したもので，衝突防 止装置と人 (両足)の位置関係によって, 超音波受信素子 がどのような反射波を検出しているかを観測した結果で ある.なお，Fig.3 の信号波形は，受信素子の信号を増幅・ 整流したものである．Fig.3(b) が示すように，衝突防止装 置に対して斜めの位置で立っている"人"に対しては反射 波を検出できない場合がある，反射波が検出できない原因

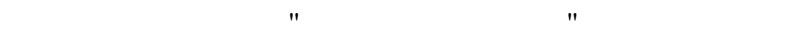
なるので，両方の足から反射される超音波に位相差が生 じ，結果的に " 両者の干渉によって反射波が得られない場 合が生ずる"ものと推察される .このため, 今回の試作装 置では壁など固体の障害物に対して有効な衝突防止装置 とした .

電動車椅子の周囲に " 人 "や犬猫などの " 動物 " が存在 するのは必然的な状況と考える。したがって，人や動物を 検知できるような衝突防止装置は必要である.現在，防犯 用センサとして使われている焦電センサによる衝突防止 装置の導入を検討中である。

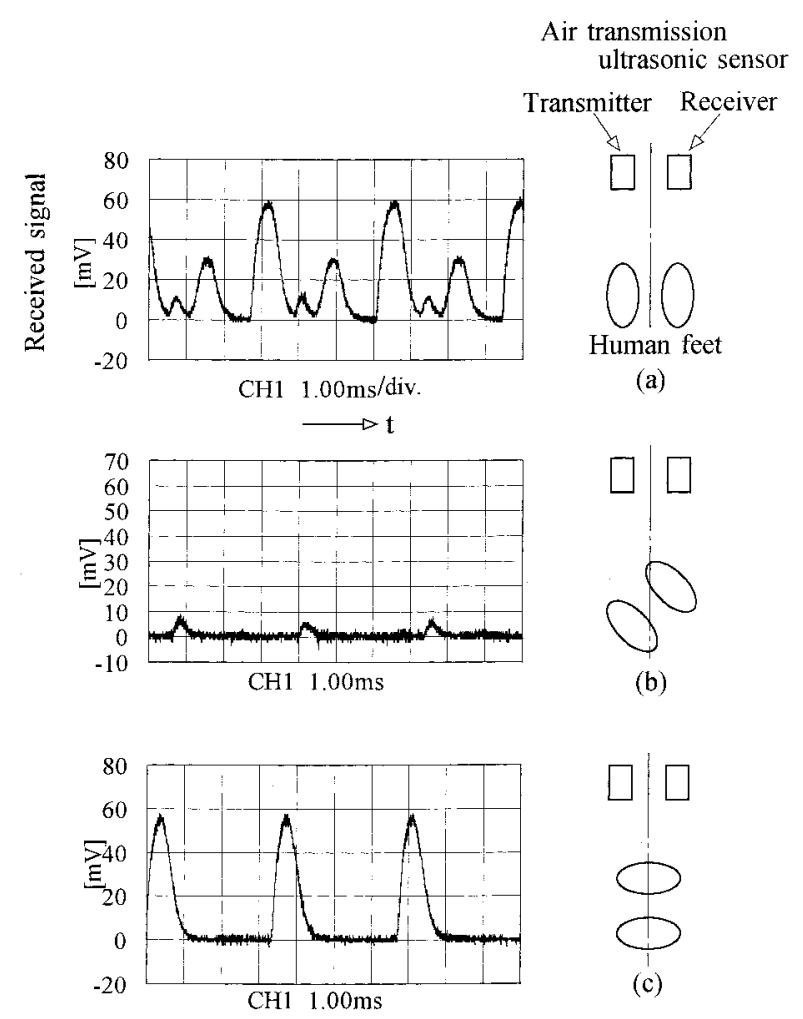

Fig.3. Ultrasonic wave patterns reflected from human feet.

\section{3. 走行方向の制御}

この章では, 本報告の中心である「搭乗者の体の動きに 合わせて走行方向を制御」するシステムについて述べる .

現在の電動車椅子の殁どは, ジョイスティックなどを操 作することにより走行方向の制御が行われている.しかし ながら，必ずしも，すべての老齡者が手足の機能を発揮で きるとは限らない. 老齡者によっては, 手足以外を使って 走行方向を制御できれば，電動車椅子を利用して自立した 日常生活を過こすすことができる人々も多い．この研究は， このような人たちに供することを狙いに，移動したい方向 を体の一部を使った動きで表現し，兴の動きをセンシング することによって走行方向を制御する電動車椅子の開発 を目的としている、すでに，視線の動きで走行方向を制御 する電動車椅子か開発されている3).これに対して，本研 究では体が動く方向をセンシングして走行方向を制御す る電動車椅子の開発を試みた . 体が動く方向は, 加速度セ ンサによって比較的容易にセンシングすることが可能で ある.さらに，加速度センサであれば取り付け部位の制約 も少ないので, 検出する動作の選択にも自由度がある .こ こでは,帽子 (試作装置ではヘルメットを使用) に取り付 けた加速度センサにて「頭部の動き」を検出し, 走行方向 を制御することを試みた。

頭部の動きを加速度センサでセンシングする方法とし ては,(1)動きの加速度をセンシングする，(2)傾斜角度をセ ンシングする，ことが考えられる。このうち, 試作装置で は(2)のセンシングを利用した .すなわち, 傾斜方向で電動 車椅子の走行方向を制御する方式とした．

\section{1 頭部の傾斜角検出}

センサとしてはアナログデバイセズ社の加速度センサ ADXL202を用いた.ADXL202を選択した主な理由は,加 速度と同時に傾斜角度をもセンシングできる点である．

センサと1チップマイコン(マイクロチップテクノロジ 社製 : PIC16F84）を組み合わせたセンサ回路をFig.4に示 す ADXL202 の原理と使い方については,テクニカルノー 卜 ${ }^{4)}$ に詳しく記載されているが, 本試作装置と関連ある 部分について，Fig.4をもとに簡単に述べる。

ADXL202 は, 測定範囲が $\pm 2 \mathrm{~g} \cdot 2$ 軸の加速度センサと して提供されている .このセンサを頭部の傾斜センサとし て使用している状況について述べる.頭部の頂点に平面を 想定する .この平面をセンサ平面と呼ぶことにする.この 平面は，背筋を伸ばした状態で重力に垂直となる．さら に，Fig.5に示すように，頭部頂点を原点とする x y z の 3 次元座標系を考える .ここで, $\mathrm{z}$ 軸の向きは反重力方 


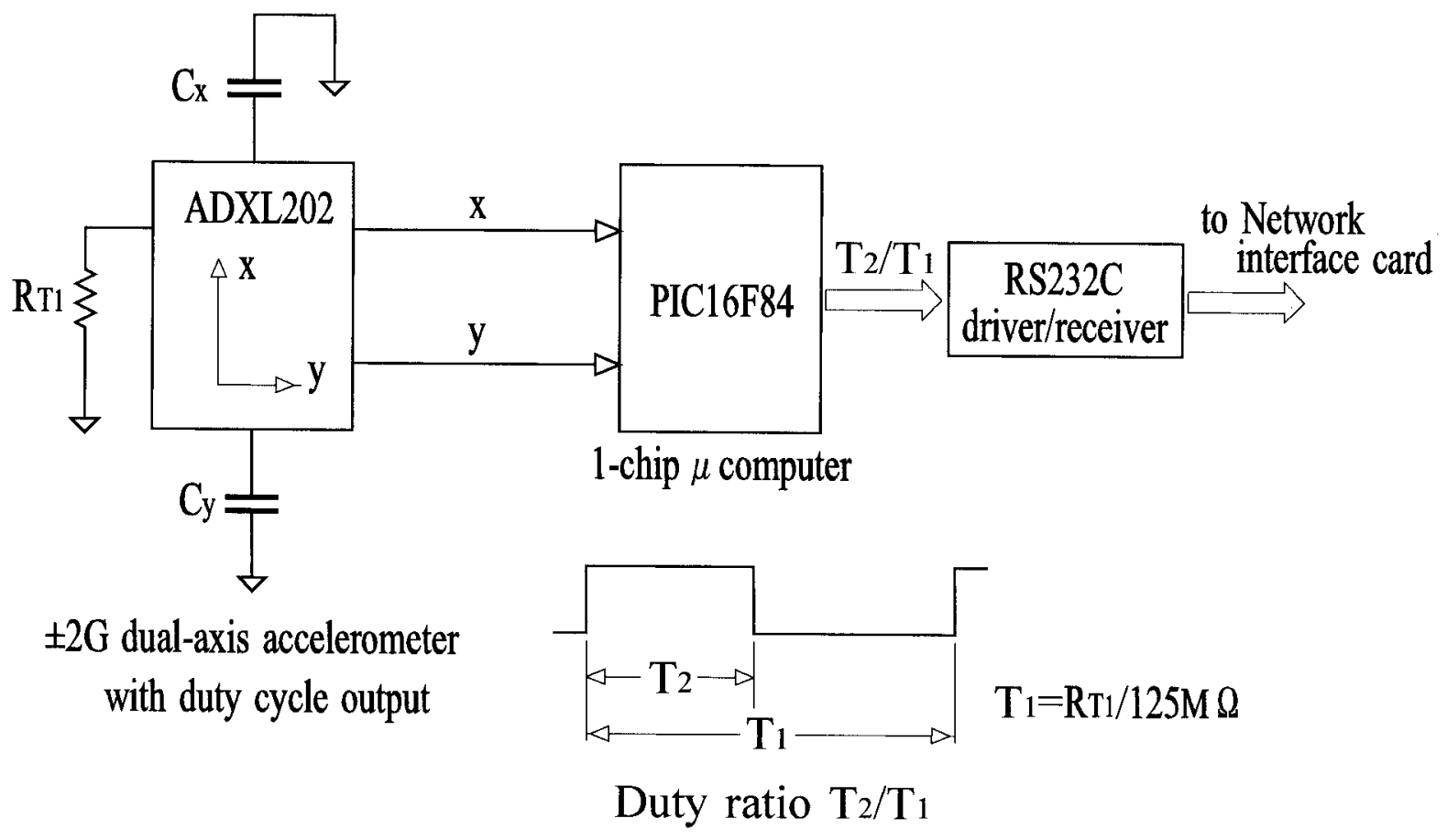

Fig.4. Block diagram for the tilt angle sensor.

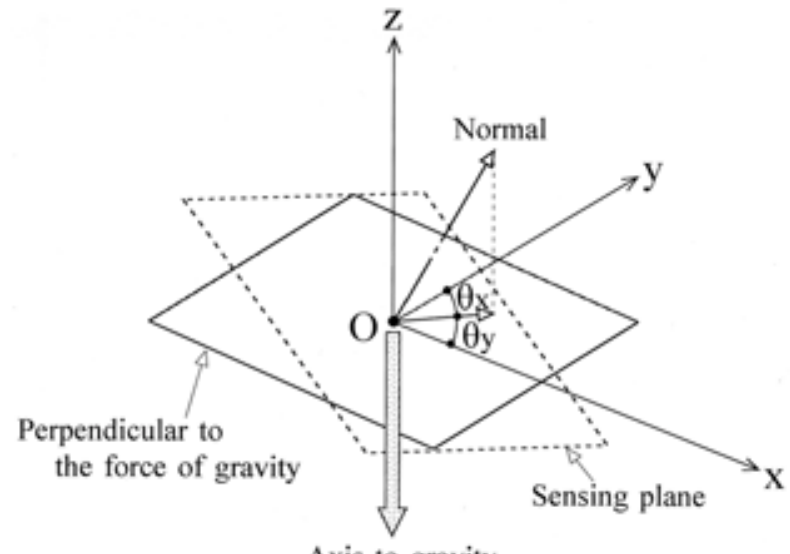

Axis to gravity

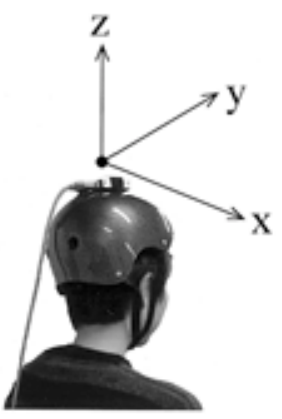

Fig.5. 3-D co-ordinate system and the tilt angle.
向, $\mathrm{x}-\mathrm{y}$ 平面は重力に垂直とする (地表に平行). また， 目線の方向を $\mathrm{y}$ 軸に,右肩の方向を $\mathrm{x}$ 軸に選ぶ。この座 標系において，ADXL202 をセンサ面上に取り付ける .こ のような状態で頭部を傾斜させるとセンサ面が $\mathrm{x}, \mathrm{y}$ 軸 に対して成す角度は，光れ光れ $\theta_{x}, \theta_{y}$ となり，センサ 面に取り付けられた傾斜センサ (ADXL202)にて $\theta_{x}, \theta$ y を得ることができる. $\theta_{x}, \theta_{y}$ を Fig.6 で説明すると， センサ面法線の $\mathrm{x}-\mathrm{y}$ 平面への射影が $\mathrm{y}-\mathrm{z}$ 平面と成す角 が $\theta$ xで, $x-z$ 平面と成す角が $\theta$ y となる.傾斜センサ の ADXL202 からはアナログとディジタル (デューティサ イクル) で $\theta_{x}, \theta_{\mathrm{y}}$ が出力されている.試作装置では1 チップマイコンとの接続性に優れるデユーティサイクル 出力 (周期 $\mathrm{T}_{1}$ に対するパルス幅 $\mathrm{T}_{2}$ の比) にて $\theta_{\mathrm{x}}, \theta_{\mathrm{y}}$ を得ている.

ADXL202 のテクニカルノートでは, 傾斜角と Duty 比 $\left(\mathrm{T}_{2} / \mathrm{T}_{1}\right)$ との関係が $\theta_{\mathrm{x}}\left(\theta_{\mathrm{y}}\right)=\sin ^{-1}\left\{\left(\mathrm{~T}_{2} / \mathrm{T}_{1}\right)-0.5\right\} / 0.125$ とな ることが示されている . この関係を図示したのが Fig.6の 曲線である . Fig.6 から, 重力に垂直な近辺と, 平行な近 辺では感度が異なることが確認されるが, 重力に垂直 (地 面に水平) な $\theta_{x}\left(\theta_{y}\right)=0$ 近辺では直線で近似することが できる.実際，頭部を鋭く傾斜させることは考えられない ので, 傾斜角は $\theta_{\mathrm{x}}\left(\theta_{\mathrm{y}}\right) \leqq \pm 45^{\circ}$ の範囲を考慮すれば十 
分で, この範囲において, 傾斜角は Duty 比で直線近似す ることができる .

Fig.6におけるくは，測定值である．原点 (水平) を移 動させるならテクニカルノートで示される值に，ほぼ一 致する . 両者の差は, 測定における水平度やセンサ固有 の誤差によるものと推察されるが, センサを取り付けた 帽子 (試作装置ではヘルメット) を装着したとき，搭乗 者が" 水平"と判断した状態を原点として選ぶことになる ので , この誤差は無視することができる . Fig.7 は測定值 をもとに,傾斜角が士 $45^{\circ}$ の範囲で直線近似したもので， 直線で十分近似できることを示している．

\section{2 走行制御}

傾斜センサのディジタル出力を 1 チップマイコンに入 カすれば,マイコンが得意とするカウントアップ機能で容 易にDuty 比が得られ，傾斜角 $\theta_{x}\left(\theta_{y}\right)$ を検出することが

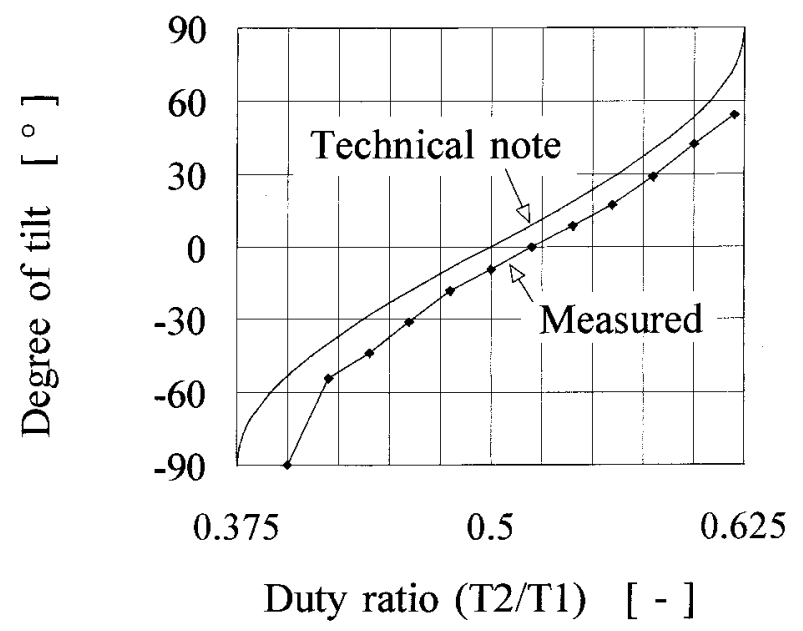

Fig.6. Output of the tilt angle sensor.

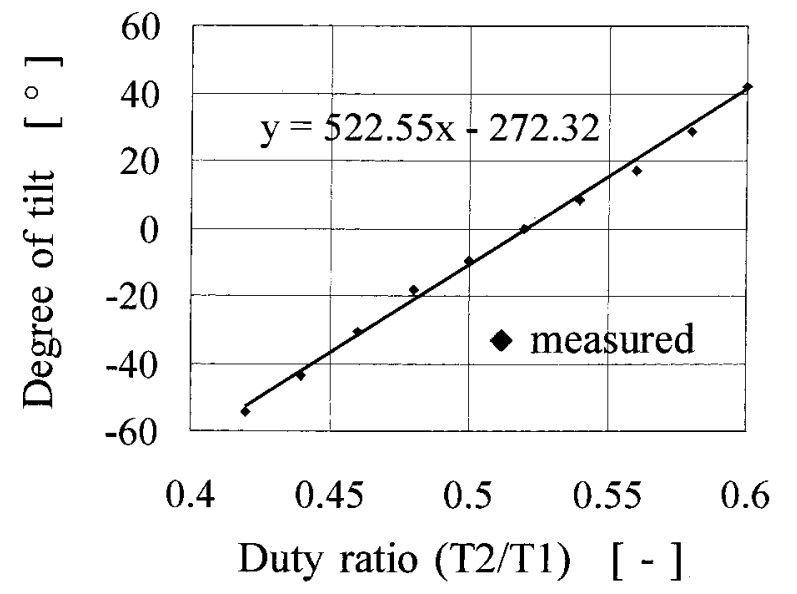

Fig.7. Linearity of the output data of the tilt angle sensor.
できる.光して，検出された頭部の傾斜角をパソコンに転 送し，パソコンにて左モータおよび右モータの回転速度を 設定し走行方向を制御する.具体的な記述は省き, 制御の 要点のみを以下に列記する .

(1) 不感帯の設定

頭部の僅かな傾きに応答して車椅子が走行するのは制御 として不適であるので, 不感帯を設けた .この不感帯は, 車 椅子に座ったときに初期設定動作の中で定めている．車椅 子に座る姿勢は個人差があるので, センサ面の初期値を設 定し，この初期值を基準面として Fig.8 に示すような立体角 の範囲を定めて不感帯とし, センサ面の法線がこの範囲内 にあるときは走行を停止させる方式としている .

(2) 走行制御

$\theta_{\text {x }} \theta_{\text {y }}$ から, 左右のモータの回転方向と速度を設 定している．速度は単に比率制御としている．

(3) 走行可能状態の検知

頭部を傾斜させても車椅子を走行させたくない場合が あるので, 車椅子が走行動作できるのは『背もたれに体を 預けているときのみ』とした . 背もたれに体を預けている 状態は圧力センサによって検知する方式とした .なお，圧 カセンサを肘掛けに取り付ければ,肘掛けに腕を乗せてい るときのみ車椅子の走行を可能とすることができる .

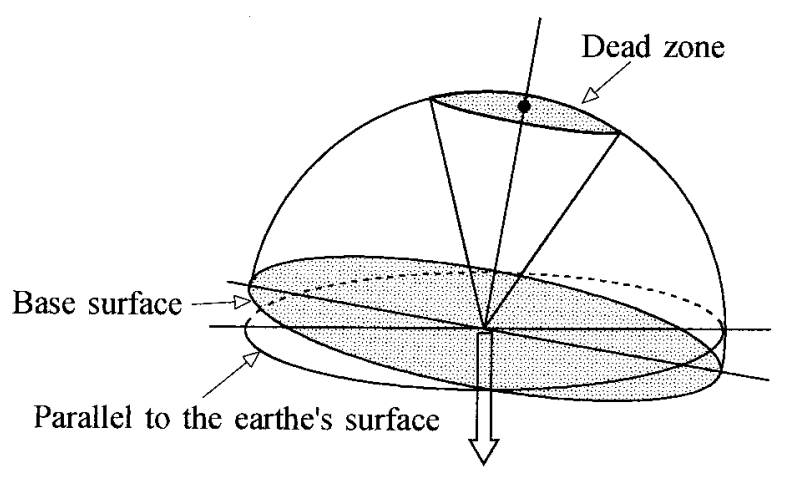

Axis to gravity

Fig.8. Dead zone of control.

\section{4 .試作結果}

試作した装置をFig.9に示す．テストにより，ほぼ設計 通りの制御が実現できることを確認した.今回の試作では 傾斜角の検出に加速度センサを用いているので, 走行中に 振動によるノイズが発生することが懸念された. ADXL202 ではフィルタキャパシタ C $x$ ， C y (Fig.4 参照) によって帯域幅を設定することができる.試作装置では帯 域幅を約 $10 \mathrm{~Hz}$ にすることによって，センサの応答性に対 する要求を満たし，なおかつ,振動によるノイズを抑制す 
ることができた .参考のため , 走行中の振動による影響を 測定した結果をFig.10 に示す . 測定は, 試作した電動車 椅子の座席に加速度センサを置き，車椅子を平坦な床面の 室内で,小刻みに前進後退ならびに左右動を繰り返した状 況での結果である.図の結果によるなら，振動による測定 データ $3 \sigma て ゙ 50$ 程度であり，殆ど無視することができる と考える

なお ,試作した車椅子は室内での使用を想定しているの で, 走行中の振動による加速度センサへの影響調査は, 床

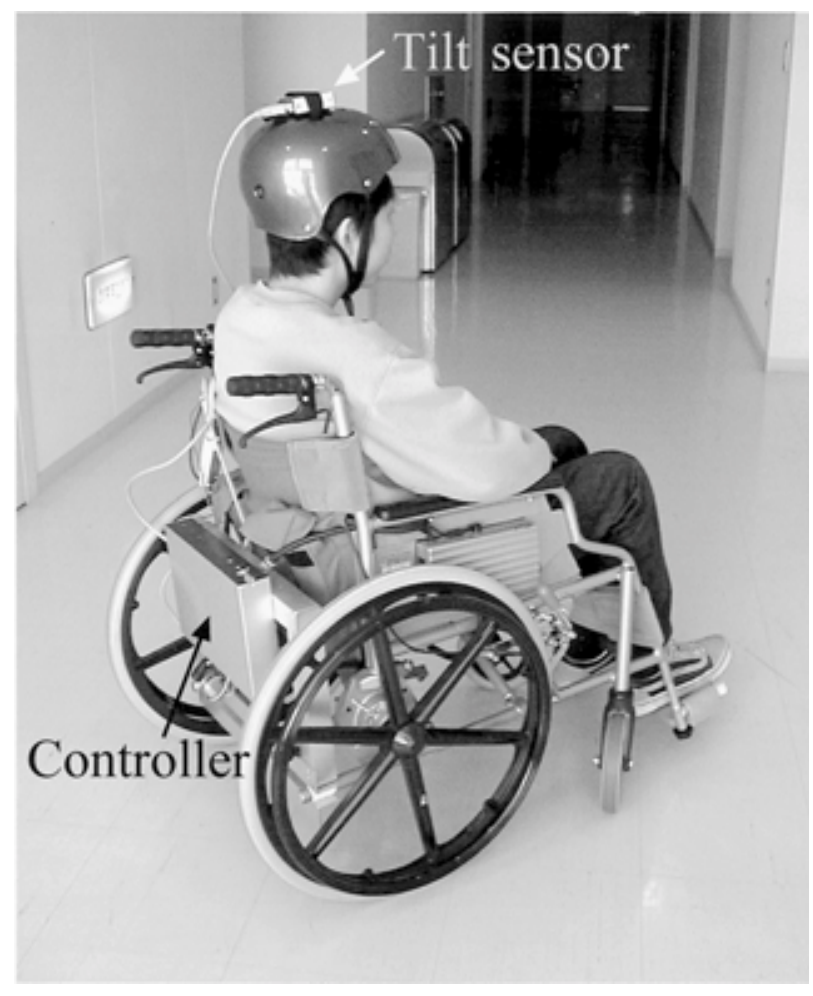

Fig.9. A prototype electric powered wheelchair that moves toward the direction of the user's reclined body.

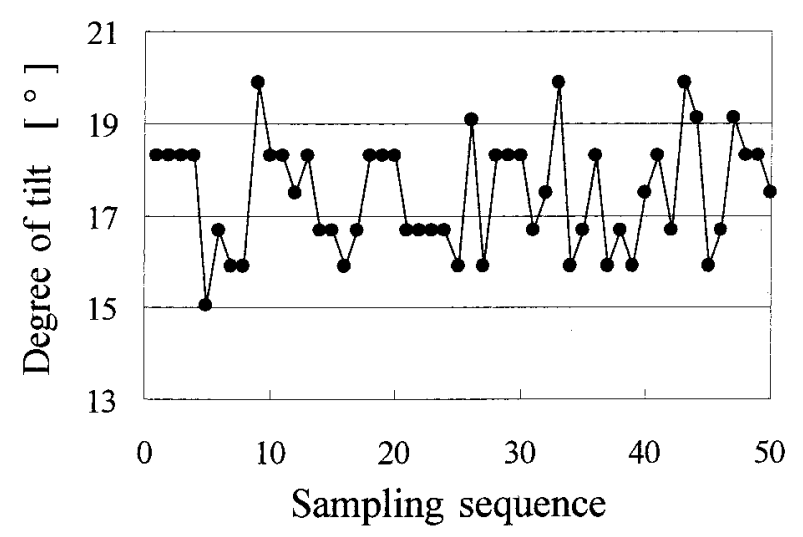

Fig.10. Suppression of vibration noise for the tilt angle sensor.
面が平坦な状況での測定に限定して実施した . また, 静止 時における測定データのバラツキ(電気的ノイズ) は $3 \sigma$ で $1.5^{\circ}$ であった .

現在 , 装置の試作が完了したところで, 実際に老齢者の 搭乗による評価がなされていないため,完成された段階に あるとは言えないが, 「(1)へルメットから帽子への変更」 「(2)帽子にはセンサのみ取り付け」を行い，センサ部を実 用的なものにしたうえで，老齢者によるテストを重ね，実 用化をめざしたいと考える .

\section{5 .おわりに}

ここでは,安価な加速度センサとノートパソコンおよび 兴の周辺汎用インターフェイスにて, 搭乗者の体の傾きに よって走行方向を制御する電動車椅子の試作について報 告した . ほぼ, 設計通りに動作することを確認したので， 今後は老齢者による使用テストを行っていく考えである． 試作装置の走行テスト状況については, ホームページ $\ulcorner$ http://cuprite.daido-it.ac.jp/`endo/」の動画で確認されたい . 老齢者介護に関しては我々にとって身近な問題であり， 医療の進歩に伴い，ますます長寿化が進むことは必然であ る.近年，飛躍的に進歩を遂げた情報技術や電子情報技術 を駆使して老齢者の自立に供し得る機器装置の開発に よって, 少しでも高齢化社会に貢献できれば幸いと考え る。

(文 献)

1)総務省統計局統計センタ:日本統計年鑑, 第2章・人口世 帯・将来人口推計, (2002).

2)国立社会保障・人口問題研究所:日本の将来人口推計， (2002).

3)例えば,伊藤智行 松本吉央, 今井正和，小笠原司: 顔と視 線方向による電動車椅子の走行支援, 第18回ロボット学 会学術講演会予稿集，(2000),405.

4)ANALOG DEVICES:テクニカルノート ,デジタル出カ 付き低価格士 $2 \mathrm{~g} \cdot 2$ 軸加速度センサー,(2003)。 